\title{
Elina Vainio
}

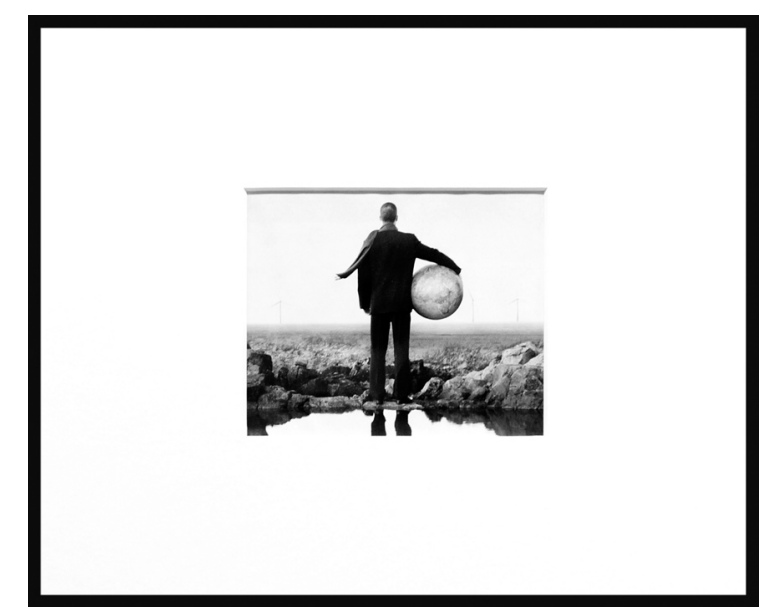

Elina Vainio: sarjasta Planet Earth Advertisements, 2007-. Suzlon (2009), $30.5 \times 25 \mathrm{~cm}$.

Elina Vainio otti Maa ilmasta -näyttelynsä lähtökohdaksi Apollo -kuulennon miehistön avaruudesta käsin ottaman valokuvan, joka esittää avaruudessa kelluvaa maapalloa. Kuva sai nopeasti ikonisen aseman ympäristöongelmien globaalin luonteen ilmentäjänä. Se esimerkiksi kuvitti iskulausetta "Only One Earth!", joka nousi YK:n vuoden 1972 ympäristökonferenssin iskulauseeksi. Sittemmin kuva on vakiintunut symboliseen käyttöön mitä erilaisimmissa yhteyksissä.

Elina Vainio (s.1981) valmistui vuonna 2006 kuvataiteen kandidaatiksi Chelsea College of Art \& Design -yliopistosta Lontoosta ja suorittaa parhaillaan maisterin tutkintoa Helsingissä kuvataideakatemian tila-aikataiteiden osastolla. Vainio on kansainvälisen Transidency-kollektiivin jäsen, ja hän on ollut osallisena useissa kollektiivin projekteissa sekä Suomessa että ulkomailla. Hänen teoksiinsa sisältyy installaatioita sekä sarjallisia kokonaisuuksia, jotka tarkastelevat nykykulttuuria ehdollistavia materiaalisen maailman konstruktioita erilaisista näkökulmista.

Maa ilmasta (Galleria Huuto, 13. - 31.7.2011) oli Vainion ensimmäinen yksityisnäyttely. Sen keskeisen osan muodosti teossarja Planet Earth Advertisements, jonka kuvia hän on kerännyt usean vuoden ajan sekä suomalaisista että ulkomaisista aikakauslehdistä. Kuvien yhteinen tekijä on Apollo-miehistön maapallokuvan käyttö mainonnassa. Töiden nimet heijastavat niiden alkuperää: "Talentum", "Nissan", "DHL", "Osuuspankki" ja niin edelleen.

Apollo-valokuva on ambivalentti. Avaruudessa kelluva maapallo on ihmiskunnan koti, mutta ilmentääkö kuva ihmiskunnan haavoittuvuutta avaruuden äärettömyydessä vai osoittaako se päinvastoin ihmiskunnan kykyä muokata maailma itselleen asuinkelpoiseksi? Kuvaa käyttävien mainosten symboliikka on yhtä lailla ambivalenttia. Joissakin muunnelmissa maapallo tuntuu olevan ihmisen (ihmiskunnan) otteessa, toisissa taas ihminen (ihmiskunta) tuntuu viettävän sopusointuista elämää maapallon pinnalla. Muutamat kuvat ovat visuaalisia vitsejä.

Ajatuksia (ja haluja) virittävä ambivalenssi on tehokkaan mainoskuvan olennainen tunnuspiirre. Juuri kuvien ambivalenssia Elina Vainio kykeneekin käyttämään hyväkseen. Hänen toteuttamansa kuvasarja nostaa esiin kysymyksen, johon emme tiedä vastausta: ilmentääkö ihmiskunnan elämä maapallolla harmoniaa ja yhteiseloa vai kasautuvia ongelmia tuottavaa räävitöntä valloitushalua?

Elina Vainio esittelee töitään kotisivullaan www.elinavainio.com. 